\title{
Mandatory IFRS Adoption and Real/Accruals Bases Earnings Management in the UK
}

\author{
Mohammad I. Almaharmeh $^{1}$, Adel Almasarwah*,2, Ali Shehadeh ${ }^{1}$ \\ ${ }^{1}$ The University of Jordan/Aqaba \\ ${ }^{2}$ The Hashemite University
}

ARTICLE INFO

\section{Article history:}

Received 18 November 2020

Revised 12 January 2021

Accepted 26 January 2021

Published 08 February 2021

\section{Keywords:}

Mandatory IFRS

Accruals earnings management (AEM)

Real earnings management (REM)

Robust Regression

JEL codes: M41, C33

\begin{abstract}
Here, the link between the mandatory adoption of International Financial Reporting Standards (IFRS) and Real Earnings Management (REM), as well as Accrual Earnings Management (AEM), will be examined for non-financial listed firms in the London Stock Exchange. Robust regression analysis of the mandatory IFRS adoption will be conducted on the panel data, as well as earnings management using three AEM models and three REM models. Mixed results with respect to the qualities of AEM and REM were notably garnered, with mandatory IFRS adoption positively relating to the Roychowdhury of abnormal cash flow and the Roychowdhury of abnormal production. Meanwhile, the Roychowdhury of abnormal discretionary expenses, standard Jones, and Kothari negatively related to mandatory IFRS adoption, whilst modified Jones showed an insignificant relation to mandatory IFRS adoption. Changes in IFRS adoption and guidelines for UK firms may have an impact on AEM and REM, and, as predicted, mandatory IFRS adoption mostly affects the Kothari model followed by the standard Jones model as proxies for accounting earnings quality.
\end{abstract}

\section{Introduction}

The goal of the International Accounting Standards Board (IASB) is to develop and promote an international set of high-quality financial reporting standards, and, in order to achieve this goal, the IASB has issued principles-based accounting standards and has taken steps towards requiring accounting measurements that better reflect a firm's economic position and performance. This also serves to further remove acceptable accounting alternatives. Indeed, opportunistic behaviour amongst managers when it comes to formulating accounting income can be reduced through such earnings management. Notably, the prior literature proposes that the mandatory adoption of IFRS is more likely to lead to high-quality accounting earnings, Roychowdhury (2006) pointing out the significance of understanding earnings management in firms in order to determine its impact on business issues worldwide. On the other hand, Barth et al. (2008) mention that IFRS adoption may not reduce earnings management, since IFRS is uncompromising in its values founded on principles. This stands in stark contrast to local GAAP, and potentially offers better chances for companies to manage their income and, thus, enhance their actions in this area.

Some past researchers, including Ahmed et al. (2013), Ball et al. (2003), and Leuz (2003), conclude that IFRS's mandatory implementation enhances the probability of more flexibility amongst managers when it comes to making in-firm decisions, considering at the moment, such direction is non-existent. Moreover, Barth et al. (2008) suggest that the mandatory adoption of IFRS is expected to mitigate accounting alternatives, which, in turn, could lead to decreasing firms' accounting number abilities. In addition, Daske et al. (2008) document how the characteristic of

\footnotetext{
* Corresponding author. 
elasticity in the principles-based IFRS standards could lead firms' managers to engage in earnings manipulation through managing their numbers.

Since IFRS became mandatory in 2005, the financial reporting environment in the United Kingdom (UK) has changed significantly, which has affected several issues in the business environment worldwide. However, earnings management is not isolated from this environment: rather, it is deemed to be one of the most significant signs for truthfully assessing firms' value and ensuring that the firms comply with accounting standards, regulations, and policies (Dichev et al., 2013). In the same vein, the prior literature states that the more diligent the earnings management, the more likely it is to lead to less information being offered about a firm's performance, as well as the fact that it is important when it comes to particular decisions being made by decision-makers (Srivastava, 2014). Accordingly, IFRS adoption is found to improve accounting numbers, earnings, and the quality of financial disclosure in both developed countries (Houqe et al., 2012; Barth et al., 2008) and developing countries (Nera et al., 2017; Ismail et al., 2013).

As outlined by Chalaki et al. (2012), with the aim of bearing in mind the variations amongst financial statements' conventional guidelines, managers' attitudes surrounding earnings, and the quality of accounting data, Accrual Based Earnings Management (AEM) and Real Earnings Management (EM) are the two methods by which earnings management (EM) is measured through. To better estimate the effect of IFRS adoption on earnings management practice, this current study investigates the impact of mandatory IFRS adoption (Callao \& Jarne, 2010) on REM and AEM (Cohen \& Zarowin, 2010) as the two proxies of earnings management.

Overall, after examining a large sample of 20,192 firm-year observations for the period 1993-2019, the results suggest that mandatory IFRS adoption leads to increases in earnings quality for UK firms. This result is considered to be robust, since multiple different measures of earnings management and test models were used. Further, according to Ismail et al. (2013), Houqe et al. (2012), and Barth et al. (2008), this conclusion (i.e., there being a positive relationship between UK firms' earnings quality and mandatory IFRS adoption) aligns with the separate conclusion that there is a positive relationship between accounting numbers' quality and high-quality accounting values.

This field has thus far largely neglected to investigate non-financial UK firms and the nature of their relationship between mandatory IFRS adoption and earnings quality, and so this specific paper endeavours to bridge this gap and shed light on this area. Indeed, as pointed out by Brüggemann et al. (2013), the current literature largely fails to make the distinction between the impact of IFRS and the impact of other factors on the quality of earnings management in firms, since they tend to investigate several countries at once. In the same vein, Oz \& Yelkenci (2018) conclude that the legal system is considered to be an important issue that has the potential to lead to different research results in a cross-country study - a conclusion that led them to recommend other researchers to focus on a single country to examine the relationship between REM, AEM, and the mandatory adoption of IFRS. Following this recommendation ( as well as that of Brüggemann et al., 2013), this study focuses on one dataset for non-financial UK firms and covers 27 years - a large sample compared to prior studies in this field. This study additionally contributes to the literature by investigating modifications in EM behaviour from AEM to REM in the UK context, using the same independent and control variables to measure their impact on earnings quality.

The structure of the remainder of the paper is as follows: Section 2 presents our hypotheses to be tested and discusses the related literature, followed by Section 3, which details our empirical methodology. Next, Section 4 discusses the results, and, finally, Section 5 presents conclusions based on the findings.

\section{Hypotheses and Related Studies}

It is possible that EM may rely on several accounting choices and policy selections, which could lead to inconsistencies between income-accounting regulation times and cash flow times (Brüggemann et al., 2013); hence, EM can be categorised into two types: AEM (which focuses on discretionary and nondiscretionary accruals [Dechow \& Dichev, 2002]) and REM (which focuses on cash flow, expenses, and productions [Roychowdhury, 2006]). In addition, Roychowdhury (2006) indicates there to be a difference between real and accrual-based earnings management when measuring their impacts on the evaluation of firms, whereas REM and AEM negatively relate to firm value, in the case of focusing managers on increasing firm earnings in the present. As a matter of fact, this is likely to lead to a decrease in cash inflow in the future - and yet capturing REM is not considered to be easy to track compared to AEM, since managers can hide their manipulation of earnings in daily business transactions by, for instance, compromising decisions about modifications in the timing or formatting of a transaction (Cohen \& Zarowin, 2010). Also, managers may incur fewer private costs with REM when compared to AEM - particularly in the shortrun - in case of catching them by diagram, for example (Roychowdhury, 2006). 
Since 2005, many studies have dealt with IFRS adoption and how its mandatory adoption operates in developing and transitioning countries. The current paper investigates the nature of the relationship between earnings management and IFRS's mandatory adoption, since earnings management is considered to be one of the most essential matters in financial reporting - particularly after the Enron and WorldCom scandals (Almasarwah, 2019).

The early literature indicates that the impact IFRS adoption has on earnings management is important for many reasons: a higher level of IFRS adoption is negatively related to earnings management. Considering the fact that the IFRS is a group of accounting regulations and principles, it may be hard to circumvent them-although the IFRS encourage using fair value accounting, which, in turn, decreases earnings management via allowing firms to more efficiently imitate fundamental financial actions, rather than using local standards. The IFRS additionally decreases choices and accounting options, thus refining accounting quality (Oz \& Yelkenci, 2018; Ipino \& Parbonetti, 2017). To address why IFRS adoption could lead to lower earnings management, we reviewed the existing literature, which provides empirical evidence of the consequences of IFRS adoption.

Proponents of IFRS adoption argue that IFRS improves transparency by increasing the quality of financial disclosure. Notably, the current combination of IASs and IFRSs has generated more than 2,000 disclosure requirements worldwide, which, in turn, increases the demand from accounting standards bodies to understand and implement such requirements (Ernst \& Young, 2006). To add to this, according to Ernst \& Young (2006), the length of the studied EU business' annual financial reports increased up to 30\% in length after IFRS employment. Ball (2006) suggests that IFRS provides more accurate and timely financial statement information than any national standards, including the local standards of EU countries.

Consistent with the notion that IFRS adoption improves the quality of financial disclosure, previous research has found that IFRS adoption yields favourable capital market consequences. A large number of studies suggest there to be an increase in the value relevance and information content of accounting numbers after IFRS adoption (Ismail et al., 2013; Tsalavoutas et al., 2012; Landsman et al., 2012; Devalle et al., 2010; Barth et al., 2008;). Likewise, Houqe et al. (2014) and Horton et al. (2013) and provide evidence to suggest that IFRS adoption improves the information environment through increasing the forecast accuracy of analysts and reducing analysts' forecast dispersion. In addition, there is a reduction in information processing costs, cash risk, and the cost of equity capital documented by many researchers (DeFond et al., 2015;; Armstrong et al., 2010; Daske et al., 2008) following IFRS adoption. Further to this, Gillberto, Loureiro \& Taboada (2012), Bissessur \& Hodgson (2012), and Beuselinck et al. (2010) all document there to be a positive relationship between IFRS adoption and transparency within stock market prices and general discussion surrounding money.

Three types of study shed light on IFRS mandatory adoption and EM worldwide: first, IFRS mandatory adoption and AEM; and second, IFRS mandatory adoption and REM; and third, a mixture of the first two, which is the relationship between IFRS's mandatory adoption and REM and AEM. Based on a sample of 250 French-listed firms during the period of 1999-2011, Sellami \& Fakhfakh (2013) found there to be a significant reduction in discretionary accruals and real EM absolute values after six years of IFRS mandatory adoption, meaning earnings quality improved significantly in the French environment. Meanwhile, Oz \& Yelkenci (2018) indicated that REM and AEM reduced significantly following mandatory IFRS adoption; however, they also found there to be a significant difference between the REM and AEM models in the detection of their estimate values based on the legal system (e.g., law origin; common law). Also, some of the early literature documented the way in which IFRS adoption led some international firms to unintentional significance by replacing REM for AEM, particularly amongst firms in countries with rigorous enforcement systems.

\section{IFRS Mandatory Adoption and Accruals Earnings Management}

The accrual element is considered to be dubious compared to the cash flow element: where accruals are the product of decisions, assessments, and apportionments, cash flows are understood (Nera et al., 2017). The management of firms are permitted to practice accrual accounting estimates - and thus, an accrual decreases or increases a manager's ability to engage in earnings management to re-evaluate a firm's performance (Dechow et al., 2010). In the same vein, Lyimo (2014) found that a low level of accrual quality leads to an increase in reported earnings quality. Notably, accrual quality has extra information that decreases variations in cash flows, thus causing the earning issue to be more valuable (Dechow \& Dichev, 2000), with it being argued that the measurement of earnings by accrual may increase earnings quality (Melumad \& Nissim, 2008). Ahmed et al. (2013) have demonstrated decreases in loss recognition timeliness and increases in income smoothing and accrual aggressiveness after adopting IFRS in 20 countries, whilst Christensen et al. (2015), Paananen \& Lin (2009), and Paananen (2008), who conducted their studies in the German context, found that income smoothing, financial reporting quality, and loss recognition timeliness all significantly 
decrease under voluntary IFRS adoption compared to mandatory IFRS adoption. Moreover, they suggest that mandatory IFRS adopters might perceive fewer benefits from principles based accounting standards (i.e., IFRS), and that they thus avoid the costs of transferring to IFRS. Jeanjean \& Stolowy (2008) have similarly documented that the pervasiveness of earnings management in Austria and the United Kingdom is less than France, and relate this responsiveness to Austria's and the United Kingdom's adoption of IFRS.

This mixed evidence has a number of explanations: according to Daske et al. (2013), some individuals who adopted IFRS did not make any real impactful changes during this time, thus leading to results reflecting fleeting impacts of initial adoption and low statistical power due to relatively short analysis periods (two to three years after the mandatory adoption) (Brüggemann et al., 2013; Jeanjean \& Stolowy, 2008). In reflection of the prior literature, we propose the following hypothesis:

H1: There is a negative relationship between the mandatory adoption of IFRS and accruals earnings management in UK firms.

\section{IFRS Mandatory Adoption and Real Earnings Management}

One of the most significant regulatory changes in accounting standards was the adoption of the IFRS, which enhances the quality of reporting and causes firms seek to add value to their shareholders. The ensuing systematic improvements of financial report quality has limited firms' executives in engaging in manipulation, and the majority of earnings management studies (Zang, 2012; Cohen \& Zarowin, 2010; Roychowdhury, 2006) document that a real earnings management approach is essential when it comes to understanding executives' behaviour and decisionmaking during the selection of a specific approach. Roychowdhury (2006) defines his model as 'deviations from the ordinary course of operations', and in his model, Roychowdhury documented executives' manipulation via boosting sales by providing additional discount and extending credit terms, which increased the current income and/or avoided losses.

Similarly, executives reduce the cost of goods sold by overproduction, since this lowers the fixed overhead cost; nevertheless, this approach is only considered to be beneficial when the cost of holding the inventory is not higher than the reduction of the fixed overhead. Lastly, executives increase earnings by reducing discretionary expenses, and, since the operating activities are mainly from sales of goods and services and productions, the downside of these methods is that cash flow will be impacted as the accelerated sales and overproduction decreases the operating cash flow. In addition, executives who select real activities are more concerned about current earnings rather future earnings, in turn impacting firms' future economic benefits. For example, executives that decrease spending on research and development or marketing expenses may lose future opportunities to innovate or entice new customers.

Prior studies (Zang, 2012; Roychowdhury, 2006) have pointed out that in real activities, executives do not have complete information about reporting earnings at the beginning of the fiscal year. Notably, actual tangible tasks can't be altered at the fiscal year's closure, whilst accrual manipulation can. Therefore, executives are more likely to manipulate in the last quarter of the fiscal year, when they are adopting the real activities approach.

Since the adoption of IFRS, studies (Lee, 2019; Wardhani \& Anggraeni, 2017; Budrina, 2014) have largely centred on the ways in which real earnings management is influenced by IFRS. Some of these studies (Burgstahler et al., 2006) reveal that IFRS emphasises professional judgement when executives exercise their right; hence, it increases the opportunity for manipulations. Nevertheless, other studies have pointed out that the adoption of IFRS improved accounting information and decreased manipulation (Lee \& Swenson, 2011), such differences in the manipulation of financial statements and IFRS possibly being due to testing different geographic areas, the sampling selection, and the methods used by the researchers. Saying this, these differences in findings motivated us to examine IFRS and the manipulation of real activities - and yet the key benefit of our approach is that we employed the last reporting quarter, which adheres to Roychowdhury's (2006) model. Given the above, we propose the following hypothesis in relation to mandatory IFRS adoption and real earnings management:

H2: There is a negative relationship between the mandatory adoption of IFRS and real earnings management in UK firms. 


\section{Methodology}

\section{Sample Construction}

Our sample comprises a large and unbalanced panel of 9,049 firm-years from 1,385 non-financial listed firms in the London Stock Exchange (LSE) between the period 1993-2019. All data was collected from the LSE and DataStream, and the analysis of the way in which earnings quality is impacted by IFRS was facilitated by the 27-year study period. This is because a long period before the adoption of IFRS could provide a better measure of earnings quality compared to a short period, which most of the prior literature has used, and because a large sample and long period of study are deemed an advantage for an empirical study, since it provides accurate results (Wang \& Yu, 2015). There are several reasons for reducing the number of firms in our study sample, and, in the same vein, financial, banking, and insurance firms have been excluded, since these have special regulations and financial accounting standards. As noted by Kim \& Shi (2012) and Hutton et al., (2009), the study sample did not include any companies that did not have the right information to measure the relevant factors, as this would have impacted the accuracy of the findings.

The current research centres on just the UK with the aim of improving the consistency of some elements (e.g., accounting disclosure obligations; regulatory atmospheres; stock listing obligations; smaller market systems), in turn facilitating us to generalise the results in similar countries and thus strengthening the reliability of our findings, as suggested by the prior literature (i.e., Paananen \& Lin, 2009; Ruland et al., 2007). In addition, Schipper (2005) states that using a single country reduces heterogeneity in the empirical results compared to cross-country studies.

We utilise a regression model in this study, whereby we use numerous measures of earnings management: real (Roychowdhury of abnormal cash flow; Roychowdhury of abnormal production; Roychowdhury of abnormal discretionary expenses); and accruals (standard Jones models; modified Jones model; the Kothari model). Further, the control measures are Return On Assets (ROA), solvency (SOLV), Return On Equity (ROE), the Leverage Ratio (LEV), the Equity Ratio (EQR), Cash from Operating Activities (CASH) and firm size (FSIZE). All of these control variables can differ significantly, and are extremely reliant on the industry; hence, it is common to compare these versus the firm's own earlier performance or its peers'.

\section{Study Variables Measurement}

\section{Earnings Quality}

In order to calculate the studied UK firms' earnings quality, the current research used accrual-based and real earnings management models, as corresponds to the current literature in this area (Doukakis, 2014; Ismail et al., 2013; Mouselli et al., 2012; Watrin and Ullmann, 2012; Rajgopal and Venkatachalam, 2011; Cohen and Zarowin, 2010; Hutton et al., 2009; Roychowdhury, 2006; Kothari et al., 2005). Our measure for REM is based on Roychowdhury (2006), where three models are used to estimate REM, including the abnormal cash flows from operations $(R O Y C F)$ :

$\frac{\mathrm{CFO}_{i, \mathrm{t}}}{\mathrm{LTA}_{\mathrm{i}, \mathrm{t}}}=\alpha\left(\frac{1}{\mathrm{LTA}_{\mathrm{i}, \mathrm{t}}}\right)+\alpha_{1} \frac{\left(\mathrm{SALES}_{\mathrm{i}, \mathrm{t}}\right)}{\mathrm{LTA}_{\mathrm{i}, \mathrm{t}}}+\mathrm{a}_{2}\left(\frac{\Delta \mathrm{SALED}_{\mathrm{i}, \mathrm{t}}}{\mathrm{LTA}_{\mathrm{i}, \mathrm{t}}}\right)+\varepsilon_{\mathrm{i}, \mathrm{t}}$

Where CFO is cash flow from operations estimated as operating income fewer total accruals, Sales and _Sales represents sales and change in sales, respectively. All variables are scaled by lagged total assets (Assets).

For discretionary expenses (ROYDIS), we use model (2) to estimate the abnormal discretionary expenses:

$\frac{\operatorname{DIS}_{i, \mathrm{t}}}{\operatorname{LTA}_{\mathrm{i}, \mathrm{t}}}=\alpha\left(\frac{1}{\mathrm{LTA}_{\mathrm{i}, \mathrm{t}}}\right)+\alpha_{1} \frac{\left(\mathrm{L}-\mathrm{SALES}_{\mathrm{i}, \mathrm{t}}\right)}{\mathrm{LTA}_{\mathrm{i}, \mathrm{t}}}+\varepsilon_{\mathrm{i}, \mathrm{t}}$

Where DIS is discretionary expenses and calculated as the sum of research and development, sales, administration, and general expenses. The other variables have been defined previously. 
The final measure used to estimate real earnings management is production cost (ROYPR). In order to adopt a reduced cost per unit (in turn leading to fewer losses with each sale [COGS]), real earnings management was employed via overproduction. We use model (3) to estimate the normal level of production cost:

$\frac{P R_{i, t}}{L T A_{i, t}}=\alpha\left(\frac{1}{L T A_{i, t}}\right)+\alpha_{1}\left(\frac{S A L E S_{i, t}}{L T A_{i, t}}\right)+a_{2}\left(\frac{\Delta S A L E S_{i, t}}{L T A_{i, t}}\right)+\left(\frac{\Delta L S A L E S_{i, t}}{L T A_{i, t}}\right)+\varepsilon_{i, t}$

Where PR is production costs defined as the sum of costs of goods sold plus the change in inventory in the year. The other variables have been defined previously.

A meta-analysis of over 300 studies concerning establishers of earnings management, concluding Kothari et al. (2005), the Modified Jones (1995) Model, and the Jones (1991) Model to all be the most commonly used models within the field when it comes to calculating the quality of earnings. Therefore, these three accrual-based models were used to measure earnings quality in this research.

In the Standard Jones Model (SJM), we use model (4) to estimate accrual-based values for SJM as below:

$\frac{T A_{i, t}}{A_{i, t-1}}=a_{1}\left(\frac{1}{A_{i, t-1}}\right)+a_{2}\left(\frac{\Delta R E V_{i, t}}{A_{i, t-1}}\right)+a_{3}\left(\frac{P P E_{i, t}}{A_{i, t-1}}\right)+\varepsilon_{i, t}$

Where TA is the total accruals for company (i) during period ( $t) ; \triangle R E V=$ the change in the revenue for company (i) during period ( $t$ ); PPE = Property, Plant and Equipment; Ai $t-1=$ the total assets for company (i) for end of period $(t-1)$; and $\varepsilon_{i t}=$ the random error.

In the Modified Jones Model (MJM), meanwhile, we used model (5) to estimate accrual-based values for MJM as below:

$\frac{T A_{i, t}}{A_{i, t-1}}=a_{1}\left(\frac{1}{A_{i, t-1}}\right)+a_{2}\left(\frac{\Delta R E V_{i, t}-\Delta R E C_{i, t}}{A_{i, t-1}}\right)+a_{3}\left(\frac{P P E_{i, t}}{A_{i, t-1}}\right)+\varepsilon_{i, t}$

Where $\triangle R E C i, t$ is the changes in account receivable for company (i) during period ( $t)$. The other variables have been defined in equation (4).

In the Kothari Model (KM), we use model (6) to estimate accrual-based values for KM as below:

$\frac{T A_{i, t}}{A_{i, t-1}}=a_{1}\left(\frac{1}{A_{i, t-1}}\right)+a_{2}\left(\frac{\Delta R^{2} V_{i, t}-\Delta R E C_{i, t}}{A_{i, t-1}}\right)+a_{3}\left(\frac{P P E_{i, t}}{A_{i, t-1}}\right)+a_{4}\left(\frac{N I_{i, t}}{A_{i, t-1}}\right)+\varepsilon_{i, t}$

Where Nii, $t$ is net income for company (i) during period ( $t$ ). The other variables have been defined in equations (4) and (5).

International Financial Reporting Standards (IFRS)

The information about IAS and IFRS that was followed when preparing the firm's financial statements for a specific firm was obtained from the DataStream database, which used the Worldscope code (WC07536). Table 1 provides a detailed explanation of the Worldscope code (WC07536) classification of IAS and IFRS for each firm, whilst 23 accounting standards employed for their financial statements were pinpointed by DataStream. Indeed, this current research mirrors that of Kim \& Shi (2012a) in the sense that it employs a full set of either IAS or IFRS, a value of 1 being provided and, if not, a value of 0 . 
Table 1. Worldscope description of accounting standards followed (Field 07536)

\begin{tabular}{|c|c|}
\hline Worldscope fields 07536 & Worldscope description \\
\hline 1 & Local standards \\
\hline 2 & International standards \\
\hline 3 & U.S. standards (GAAP) \\
\hline 4 & Commonwealth countries standards \\
\hline 5 & EU standards \\
\hline 6 & International standards and some EU guidelines \\
\hline 7 & Specific standards set by the group \\
\hline 8 & Local standards with EU and IASC guidelines \\
\hline 9 & Not disclosed \\
\hline 10 & Local standards with some EU guidelines \\
\hline 11 & Local standards - inconsistency problems \\
\hline 12 & International standards - inconsistency problems \\
\hline 13 & US standards - inconsistency problems \\
\hline 14 & Commonwealth standards - inconsistency problems \\
\hline 15 & EEC standards - inconsistency problems \\
\hline 16 & International standards and some EU guidelines - inconsistency problems \\
\hline 17 & Local standards with some OECD guidelines \\
\hline 18 & Local standards with some IASC guidelines \\
\hline 19 & Local standards with OECD and IASC guidelines \\
\hline 20 & US GAAP reclassified from local standards \\
\hline 21 & Local standards with a certain reclassification for foreign companies \\
\hline 22 & Other \\
\hline 23 & IFRS \\
\hline
\end{tabular}

\section{Control Variables}

In addition to our accounting standards, we also identified a number of control variables in our earnings quality evaluation model for completeness (Almasarwah et al., 2018; Adams \& Jiang, 2016; Kalelkar, 2016): first, the majority of existing studies identify that a firm's size is an important factor that generally affects earnings management; however, firm size and IFRS also possibly relate to one another in the sense that larger firms generally have more agency problems, hence requiring the integration of stronger accounting standards (Wardhani \& Anggraeni, 2017; Budrina, 2014). That being said, opportunities and prospects for financial manipulation are far fewer. We notably measure firm size (FISZE) using the natural logarithm of year-end total assets and hypothesise a negative sign when it is specified as a regressor for earnings management.

Other IFRS adoption and earnings management research suggests firm solvency, particularly in those countries with strong accounting standards and regulations (and possibly due to the greater oversight of more complex organisational structures). These also determine less engaging in earnings management (Almasarwah, 2019; Yamani \& Almasarwah, 2019). We measure this using firm subsidiary (SOLV). Lastly, high cash flow from operating activities (CASH) is also more likely to lead to a decrease in earnings management, which, in turn, attracts more investors (Almasarwah, 2019). We measure this using cash flow from operating activities, divided by year-beginning total assets. We expect both SOLV and CASH to display negative signs on their coefficients (Fernandez et al., 2019; Ibhagui \& Olokoyo, 2018).

We succeed in pinpointing separate ways in which sufficient accounting and reduced earnings result in enhanced quality of firm earnings by highlighting the other factors (i.e., ROE, LEV, ROA, and EQR) that also influence earnings management and overall accounting values and bearing them in mind as control variables (Almasarwah, 2019; Ben-Nasr \& Cosset, 2014; McInnis \& Collins, 2011; Gul Srinidhi et al., 2011). Thus, we expect all ROA, ROE, $\mathrm{EQR}$ and LEV to display negative signs on their coefficients with earnings management. Table 2 summarises the study variables definitions and measurements. 
Table 2. Variable definitions

\begin{tabular}{|c|c|c|c|}
\hline Group & Variable & Code & Measurement \\
\hline $\begin{array}{l}\text { Independent } \\
\text { variables }\end{array}$ & $\begin{array}{l}\text { International Financial } \\
\text { Reporting Standards }\end{array}$ & IFRS & $\begin{array}{l}\text { This variable was measured by using dummy variable } \\
\text { with value } 1 \text { if firm adopt IFRS to prepare financial } \\
\text { statement and value } 0 \text { otherwise. }\end{array}$ \\
\hline \multirow{6}{*}{ 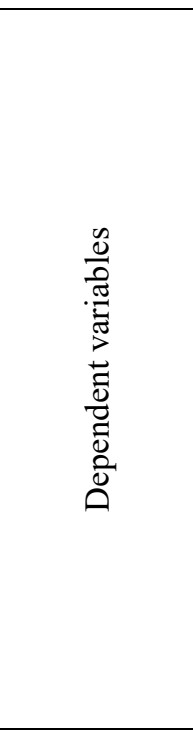 } & $\begin{array}{l}\text { Roychowdhury (Abnormal } \\
\text { Cash Flow) }\end{array}$ & ROYCFO & $\begin{array}{l}\text { This variable was measured by using standard } \\
\text { prediction abnormal cash flow from the Roychowdhury } \\
\text { Model. }\end{array}$ \\
\hline & $\begin{array}{l}\text { Roychowdhury (Abnormal } \\
\text { Discretionary Expenses) }\end{array}$ & ROYDIS & $\begin{array}{l}\text { This variable was measured by using standard } \\
\text { prediction abnormal discretionary expenses flow from } \\
\text { the Roychowdhury Model }\end{array}$ \\
\hline & $\begin{array}{l}\text { Roychowdhury (Abnormal } \\
\text { Production) }\end{array}$ & ROYPRO & $\begin{array}{l}\text { This variable was measured by using standard } \\
\text { prediction abnormal production from the } \\
\text { Roychowdhury Model }\end{array}$ \\
\hline & Standard Jones Model & SJM & $\begin{array}{l}\text { This variable was measured by using standard } \\
\text { prediction errors from the Standard Jones Model. }\end{array}$ \\
\hline & Modified Jones Model & MJM & $\begin{array}{l}\text { This variable was measured by using standard } \\
\text { prediction errors from the Modified Jones Model. }\end{array}$ \\
\hline & Kathori Model & $\mathrm{KM}$ & $\begin{array}{l}\text { This variable was measured by using standard } \\
\text { prediction errors from the Kathori Model. }\end{array}$ \\
\hline \multirow{7}{*}{ 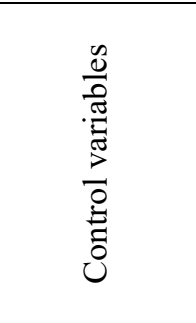 } & Return on Assets & ROA & Net income divided by average total assets. \\
\hline & Solvency Ratio & SOLV & Net income divided by total Liabilities. \\
\hline & Return on Equity & ROE & Net income divided by shareholders' equity \\
\hline & Leverage Ratio & LEV & Total Liabilities divided by total assets. \\
\hline & Equity Ratio & EQR & Total Liabilities divided by total equity. \\
\hline & $\begin{array}{l}\text { Cash from Operating } \\
\text { Activities }\end{array}$ & $\mathrm{CASH}$ & $\begin{array}{l}\text { Cash flow from operating activities divided by total } \\
\text { assets at the beginning of a year. }\end{array}$ \\
\hline & Firm Size & FSIZE & Total assets at year-end for each firm. \\
\hline
\end{tabular}

\section{Results}

\section{Descriptive Statistics}

Table 3 details the means, standard deviations, median, maximum, and minimum for the six dependent earnings management variables and mandatory IFRS adoption as both independent and control variables. Table 3 demonstrates the fact that there is not much difference between the value of abnormal accruals calculated using the Jones Model (SJM) and those calculated using the Modified Jones Model (MJM); the mean and median value of SJM and MJM are $0.002(0.001)$ and 0.09 and 0.097 respectively. In addition, ROYDIS is the model that most frequently presents a higher mean, followed by ROYPRO and then ROYCFO, with values of $0.408,0.228,-0.010$ and 0.177 , respectively. 
Table 3. Descriptive statistics

\begin{tabular}{lccccc}
\hline \multicolumn{1}{c}{ Variables } & Mean & Std. dev. & Median & Max. & Min. \\
\hline IFRS & 0.417 & 0.493 & 0.000 & 1.000 & 0.000 \\
ROYCFO & 0.177 & 0.246 & 0.000 & 1.413 & 0.109 \\
ROYDIS & 0.408 & 0.273 & 0.110 & 1.818 & 0.323 \\
ROYPRO & 0.228 & 0.306 & 0.000 & 3.582 & 0.141 \\
SJM & 0.002 & 0.008 & -0.090 & 0.056 & 0.003 \\
MJM & 0.001 & 0.009 & -0.097 & 0.048 & 0.001 \\
KM & -0.011 & 0.027 & -0.156 & 0.359 & -0.014 \\
ROA & -0.042 & 0.307 & -3.909 & 0.474 & 0.036 \\
SOLV & -0.163 & 1.039 & -11.483 & 20.856 & 0.066 \\
ROE & -0.030 & 0.925 & -9.600 & 5.323 & 0.084 \\
LEV & 0.548 & 1.464 & 0.023 & 203.825 & 0.515 \\
EQR & 1.391 & 3.654 & -34.594 & 46.587 & 0.960 \\
CASH & 0.041 & 0.226 & -8.497 & 0.476 & 0.083 \\
FSIZE & 1.809 & 1.012 & -1.081 & 4.761 & 1.757 \\
\hline
\end{tabular}

In terms of the IFRS average, this appears to broadly indicate that UK firms are weak in their IFRS adoption during the period both before and after adoption. Notably, our supposition that the extent to which IFRS is implemented within UK companies could be impacted by variations in earnings management standards is backed by the fact that there is significant variation amongst earnings management models' values, thus suggesting that this is likely to occur in our own model.

\section{Correlation, Multicollinearity, and Heteroscedasticity}

As a fractional test of the possibility for harmful multicollinearity in our regression analysis to follow, we also investigate the statistically significant pairwise associations between variables. Table 4 provides the Pearson productmoment correlation coefficients between the AEM, REM, mandatory IFRS adoption, and control variables, whilst for alternative earnings management, Table 4 shows that the correlation between real- and accrual-based earnings management measures and other variables are relatively small, the highest correlation coefficient being $54.4 \%$ (between SJM and ROA). Further, the multicollinearity should not pose any issue to the information collected considering there is not a correlation coefficient that is larger than $80 \%$.

Table 4. Correlation coefficients

\begin{tabular}{|c|c|c|c|c|c|c|c|c|c|c|c|c|c|c|}
\hline Variables & IFRS & ROYCFO & ROYDIS & ROYPRO & SJM & MJM & KM & ROA & SOLV & ROE & LEV & EQR & CASH & FSIZE \\
\hline IFRS & 1.000 & & & & & & & & & & & & & \\
\hline ROYCFO & 0.016 & 1.000 & & & & & & & & & & & & \\
\hline ROYDIS & $\begin{array}{c}0.017 \\
-\end{array}$ & 0.069 & 1.000 & & & & & & & & & & & \\
\hline ROYPRO & $\begin{array}{c}0.016 \\
-\end{array}$ & 0.379 & 0.119 & 1.000 & & & & & & & & & & \\
\hline SJM & 0.001 & -0.438 & -0.045 & -0.247 & 1.000 & & & & & & & & & \\
\hline MJM & $\begin{array}{c}0.006 \\
-\end{array}$ & -0.280 & 0.008 & -0.111 & 0.655 & 1.000 & & & & & & & & \\
\hline $\mathrm{KM}$ & 0.004 & 0.232 & 0.015 & 0.182 & 0.159 & 0.028 & $\begin{array}{c}1.000 \\
-\end{array}$ & & & & & & & \\
\hline ROA & 0.008 & -0.369 & -0.019 & -0.176 & 0.544 & 0.468 & $\begin{array}{c}0.392 \\
-\end{array}$ & 1.000 & & & & & & \\
\hline SOLV & 0.000 & -0.319 & -0.014 & -0.138 & 0.343 & 0.277 & $\begin{array}{c}0.423 \\
-\end{array}$ & 0.639 & 1.000 & & & & & \\
\hline ROE & $\begin{array}{c}0.005 \\
-\end{array}$ & -0.120 & 0.002 & -0.044 & $\begin{array}{c}0.223 \\
-\end{array}$ & $\begin{array}{c}0.190 \\
-\end{array}$ & $\begin{array}{c}0.184 \\
-\end{array}$ & $\begin{array}{c}0.354 \\
-\end{array}$ & 0.313 & 1.000 & & & & \\
\hline EQR & $\begin{array}{c}0.001 \\
-\end{array}$ & -0.067 & 0.015 & -0.017 & 0.019 & 0.036 & $\begin{array}{c}0.042 \\
-\end{array}$ & 0.051 & 0.051 & 0.214 & $\begin{array}{c}0.123 \\
-\end{array}$ & 1.000 & & \\
\hline CASH & 0.010 & -0.450 & -0.021 & -0.203 & 0.199 & 0.168 & $\begin{array}{c}0.651 \\
-\end{array}$ & 0.749 & 0.590 & 0.283 & 0.117 & 0.066 & 1.000 & \\
\hline FSIZE & 0.007 & -0.103 & 0.007 & -0.088 & 0.092 & 0.023 & 0.082 & 0.119 & 0.122 & 0.068 & 0.071 & 0.033 & 0.145 & 1.000 \\
\hline
\end{tabular}


The tolerance and Variance Inflation Factors (VIFs) are demonstrated in Table 5 so as to more effectively explore the possibility of regressive multicollinearity. As a rule of thumb, VIFs that are less than 10 and tolerances of more than 0.2 suggest no serious multicollinearity - and, as shown in Table 5, we meet these criteria for all of all our dependent, independent, and control variables, and, accordingly, we suggest that there is no prospect for harmful multicollinearity overall.

Table 5. VIF and Tolerance Results for all Models

\begin{tabular}{|c|c|c|c|c|}
\hline & \multicolumn{2}{|c|}{ Real Earnings Management } & \multicolumn{2}{|c|}{ Accruals Earnings Management } \\
\hline & \multicolumn{2}{|c|}{ ROYCFO, ROYDIS and ROYPRO } & \multicolumn{2}{|c|}{ SJM, MJM and KM } \\
\hline & $V I F$ & Toler. & $V I F$ & Toler. \\
\hline IFRS & 1.000 & 0.999 & 1.000 & 0.999 \\
\hline ROA & 3.330 & 0.301 & 3.330 & 0.301 \\
\hline SOLV & 2.110 & 0.474 & 2.110 & 0.474 \\
\hline ROE & 1.290 & 0.777 & 1.290 & 0.777 \\
\hline LEV & 1.380 & 0.726 & 1.380 & 0.726 \\
\hline EQR & 1.110 & 0.898 & 1.110 & 0.898 \\
\hline $\mathrm{CASH}$ & 2.410 & 0.415 & 2.410 & 0.415 \\
\hline FSIZE & 1.030 & 0.969 & 1.030 & 0.969 \\
\hline
\end{tabular}

However, one problem that is very likely to arise when using firm-level data is heteroscedasticity, especially when linking cross-sectional and time-series data, as was the case in this study. We use the Breusch-Pagan/Cook-Weisberg to test for heteroscedasticity and the $\chi^{2}$ values ( $\mathrm{p}$-values in brackets) as significant for ROYCFO $=9232.37(<0.001)$, ROYDIS $=3446.38(<0.001)$, ROYPRO = $80.77(<0.001), \mathrm{SJM}=20659.61(<0.001), \mathrm{MJM}=7544.44(0.001)$ and $\mathrm{KM}=29433.68(0.001)$, indicating that this is, indeed, the case the majority of the time. We would conventionally address this using nonparametric regression, but for our analysis, we select robust regression.

Table 6. Heteroskedasticity for all Models

\begin{tabular}{|c|c|c|c|}
\hline \multicolumn{4}{|c|}{$\begin{array}{c}\text { Breusch-Pagan/Cook-Weisberg test for } \\
\text { H0: Constant variance } \\
\text { Variables: fitted values of } V\end{array}$} \\
\hline \multicolumn{4}{|c|}{ Real Earnings Management } \\
\hline & Model (ROYCFO) & Model (ROYDIS) & Model (ROYPRO) \\
\hline Chi2(1) & 9232.37 & 3446.38 & 80.77 \\
\hline Prob $>$ chi 2 & 0.000 & 0.000 & 0.000 \\
\hline \multicolumn{4}{|c|}{ Accruals Earnings Management } \\
\hline & Model (SJM) & Model (MJM) & Model (KM) \\
\hline Chi2(1) & 20659.61 & 7544.44 & 29433.68 \\
\hline Prob $>$ chi 2 & 0.000 & 0.000 & 0.000 \\
\hline
\end{tabular}

\section{Multivariate Analysis}

Table 7 provides the estimated coefficients and t-statistics of the six robust regression models, each specifying an alternate measure of firm performance (ROYCFO, ROYDIS, ROYPRO, SJM, MJM and KM). For comparison purposes, we also estimated the models using ordinary least squares (OLS), assuming common, GLS, and fixed regression effects (results not shown), and, in all cases, the diagnostic tests indicated that our robust effects regression approach was superior. As demonstrated, all the models in Table 7 are highly significant overall and partially reject the null hypotheses that the slope coefficients are jointly zero at the 0.01 level. In terms of goodness-of-fit, the models explain between $0.003 \%$ (ROYPRO) and $46 \%$ (KM) of the variation in earnings management. 
Table 7. Robust regression estimates for all Models

\begin{tabular}{|c|c|c|c|c|c|c|}
\hline \multicolumn{7}{|c|}{ Panel (A) } \\
\hline & \multicolumn{2}{|c|}{ Model (ROYCFO) } & \multicolumn{2}{|c|}{ Model (ROYDIS) } & \multicolumn{2}{|c|}{ Model (ROYPRO) } \\
\hline & Coef. & t-value & Coef. & t-value & Coef. & t-value \\
\hline IFRS & 0.006 & $1.950 *$ & -0.010 & $-2.230 * *$ & 0.009 & $2.300 * *$ \\
\hline ROA & -0.018 & -0.950 & -0.012 & -0.560 & 0.022 & $1.750 *$ \\
\hline SOLV & -0.021 & $-4.840 * * *$ & -0.014 & $-2.710 * * *$ & -0.008 & $-2.620 * * *$ \\
\hline ROE & 0.003 & 0.910 & 0.005 & 1.380 & 0.001 & 0.600 \\
\hline LEV & 0.030 & $3.030 * * *$ & 0.069 & $5.780 * * *$ & 0.049 & $5.870 * * *$ \\
\hline EQR & -0.003 & $-4.500 * * *$ & -0.001 & -0.700 & 0.001 & 1.350 \\
\hline CASH & -0.416 & $-19.710 * * *$ & -0.215 & $-9.130 * * *$ & -0.023 & -1.610 \\
\hline FSIZE & -0.009 & $-5.430 * * *$ & -0.020 & $-8.240 * * *$ & 0.002 & 0.820 \\
\hline CONST. & 0.192 & $31.460 * * *$ & 0.239 & $30.890 * * *$ & 0.374 & $62.100 * * *$ \\
\hline T-statistics & \multicolumn{2}{|c|}{$157.52 * * *$} & \multicolumn{2}{|c|}{$49.33 * * *$} & \multicolumn{2}{|c|}{$7.07 * * *$} \\
\hline$R^{2}$ & \multicolumn{2}{|c|}{0.211} & \multicolumn{2}{|c|}{0.050} & \multicolumn{2}{|c|}{0.003} \\
\hline \multicolumn{7}{|c|}{ Panel (B) } \\
\hline & \multicolumn{2}{|c|}{ Model (SJM) } & \multicolumn{2}{|c|}{ Model (MJM) } & \multicolumn{2}{|c|}{ Model (KM) } \\
\hline IFRS & 0.000 & $-2.550 * *$ & 0.000 & -0.880 & -0.001 & $-2.770 * * *$ \\
\hline ROA & 0.019 & $22.610^{* * *}$ & 0.022 & $21.160 * * *$ & 0.022 & $10.300 * * *$ \\
\hline SOLV & 0.001 & $6.010 * * *$ & 0.001 & $3.520 * * *$ & -0.003 & $-6.060 * * *$ \\
\hline ROE & 0.000 & $3.920 * * *$ & 0.001 & $3.670 * * *$ & 0.000 & -0.960 \\
\hline LEV & -0.002 & $-8.220 * * *$ & -0.001 & $-4.110 * * *$ & -0.006 & $-5.930 * * *$ \\
\hline EQR & 0.000 & $4.290 * * *$ & 0.000 & $5.220 * * *$ & 0.000 & 1.380 \\
\hline $\mathrm{CASH}$ & -0.017 & $-21.080 * * *$ & -0.018 & $-17.860 * * *$ & -0.096 & $-36.890 * * *$ \\
\hline FSIZE & 0.000 & $9.720 * * *$ & 0.000 & -1.450 & 0.001 & $3.580 * * *$ \\
\hline CONST. & 0.004 & $27.700^{* * *}$ & 0.003 & $16.520 * * *$ & -0.004 & $-7.100 * * *$ \\
\hline T-statistics & \multicolumn{2}{|c|}{$204.32 * * *$} & \multicolumn{2}{|c|}{$140.55 * * *$} & \multicolumn{2}{|c|}{$266.17 * * *$} \\
\hline$R^{2}$ & \multicolumn{2}{|c|}{0.409} & \multicolumn{2}{|c|}{0.299} & \multicolumn{2}{|c|}{0.460} \\
\hline
\end{tabular}

Notes: Asterisks denote significance at the $* * *-0.01, * *-0.05$, and $*-0.10$ level.

Turning first to the estimated coefficients for the variables describing IFRS adoption, Table 7 presents the results of the robust regressions in order to test the relationship between REM and AEM and mandatory IFRS adoption. Panel A in Table 7 reports the estimated results for the REM models based on Roychowdhury (2006), whilst Panel B reports the estimated results for the AEM models based on Jones (1991), as per Kothari et al. (2005) and Dechow et al. (1995). The findings reveal more heterogeneous results, whereby the table shows that the coefficient on the IFRS variable is significant and positive for two measures of REM; ROYCFO $=1.950(<0.01)$ and $\mathrm{ROYPRO}=2.300$ $(<0.001)$. This result suggests that the adoption of IFRS-based accounting standards is significantly associated with a higher level of earnings management, and is measured by ROYCFO and ROYPRO; or, in other words, that the extent of reported cash flow from operations and production cost departure from normal ones is higher after the adoption of the IFRS, suggesting that real earnings management, as estimated by these two variables, are higher after the mandatory adoption of IFRS. Cohen et al. (2008) suggest that managers prefer REM because it may be difficult to detect compared to AEM. Meanwhile, Chen \& Huang (2013) and Graham et al. (2005) document the use by managers of 'harder to detect' REM instead of AEM after the application of a stricter regulatory mechanisms, such as the Sarbanes-Oxley Act (SOX).

On the other hand, the mandatory IFRS adoption variable reports a negative effect on all three measures of AEM, and it is significant for SJM and KM, $-2.550(<0.001)$ and $-2.770(<0.001)$ respectively. These results are consistent with the arguments of previous scholars (e.g., Ismail et al., 2013; Aksu \& Espahbodi, 2012; Houqe et al., 2012; Ballas et al., 2010; Doukakis, 2010; Barth et al., 2008), who argue that higher quality accounting standards are more likely to lead to higher quality earnings in terms of both number and transparency. In addition, they refer this to the IFRS as limiting managerial discretion, which provides greater disclosure requirements compared to local accounting standards, such as GAAP. Bhattacharya et al. (2012) suggest that a higher transparency facilitates the detection of earnings management. Hence, it is expected that IFRS adoption will reduce AEM attempts by firms' managers, especially in light of the devastating negative consequences the firm will face if earnings manipulation is uncovered (Rodriguez-Ariza et al., 2016; Lundholm, 1999; Dechow et al., 1995).

Finally, we examined the impact of our control variables on earnings management, as variously measured. As expected, all AEM models positively and significantly related to firm size and partially related to REM, particularly in ROYPRO. The presence of solvency also appeared to reduce earnings management through REM and increases 
AEM, whereas a negative relationship arose between REM and solvency compared to a positive relationship between AEM and solvency. These different results could relate to the method of calculating earnings management estimation between REM and AEM, as documented in the prior literature (Brüggemann et al., 2013; Roychowdhury, 2006; Dechow \& Dichev, 2002). ROA and ROE mostly have a positive relationship with REM and AEM, which indicates that increasing firm investment is more likely related to a higher level of earnings management. This result is expected since increasing firms investment is considered one of the motivations of earnings management (Almasarwah, 2019). In the same vein, EQR shows a positive relationship with AEM, which is consistent with ROE results whereby both variables are overlapping in their formula structures. In contrast, EQR negatively related to REM, particularly with ROYCFO. This result is unsurprising, since ROYCFO focuses on cash from operating activities, where the firm could reduce cash to avoid paying more taxes as a motivation of REM. Finally, there is a different relationship between earnings management and leverage: leverage had a positive effect on REM and a negative impact on AEM, which means that leverage relates to earnings management based on the EM motivations that the firms' managers use to achieve their desired objectives (see Velury \& Jenkins, 2006; Eng and Mak, 2003).

\section{Conclusion}

This paper has examined the association between the three REM and three AEM models as proxies for earnings management and mandatory IFRS adoption for non-financial listed firms in the London Stock Exchange (LSE) from the period 1993-2019. The period selected was particularly interesting, since it corresponded with the staggered implementation of the UK's new corporate governance code and guidelines. The expectation here was that these would significantly improve corporate governance in the country, alongside an expected increase in firm performance.

The results with respect to the quality of earnings management, which we measured using the Standard Jones Model, Modified Jones Model, and Kothari Model for AEM, and Abnormal Cash Flow Model, Abnormal Production Model, and the Abnormal Discretionary Expenses Model for REM, are somewhat mixed: the IFRS variable is significant and positive for two measures of REM (ROYCFO and ROYPRO), and is significant and negative for measures of AEM (SJM and KM). Finally, our control variables have different effects on earnings management, which has been widely documented.

This study documents clear and novel evidence for whether the mandatory adoption of IFRS reduces the earnings management of UK firms, and, when it comes to policymakers and those who utilise accounting data, the results may wield consequences. Indeed, this study has clearly concluded that a given company's accrual-based earnings management can be lessened with IFS adoption. Therefore, these findings could benefit accounting information users in this respect. However, IFRS adoption increases are hard to detect in real earning management activities. The conclusions drawn from this research may also provide needed data concerning whether or not UK firms should adopt IFRS, since this is an area policymakers currently are known to struggle with.

A challenging feature of our results is the different earnings management measurements and guideline regimes through which these firms have progressed during our sample period; moreover, it would appear that the nature of earnings management model formula structures could be the main reason behind the various impacts of IFRS adoption on earnings management activities. One possibility is that regulations and guidelines for accounting standards in the UK merely result in substantial changes to the adoption of IFRS and earnings management. It is also likely that firms began to make the necessary changes in anticipation of these changes as a means of strengthening their organisational legitimacy by aligning their accounting standards with the expectations of the investor community.

There is certainly a need for more research surrounding the proxies typically employed in assessing earnings management; here, it is argued that quantitative measures of the earnings management level by using AEM and REM will provide more accurate results when compared with prior literature, since this will help determine if UK firms comply more with accounting standards before or after IFRS adoption. At the least, this would further ensure the robustness of the present results and any similar findings. 


\section{References}

Adams, M. and Jiang, W. (2016). 'Do outside directors influence the financial performance of risk-trading firms? Evidence from the UK insurance industry'. Journal of Banking and Finance, 64, pp. 36-51.

Ahmed, A. S., Neel, M., and Wang, D. (2013). 'Does mandatory adoption of IFRS improve accounting quality? Preliminary evidence'. Contemporary accounting research, 30(4), pp. 1344-1372.

Aksu, M. H., and Espahbodi, H. (2012). 'Impact of IFRS adoption and corporate governance principles on transparency and disclosure: the case of Istanbul stock exchange'. Emerging Markets Finance and Trade.

Almasarwah, A. (2019). 'Discretionary accruals and ownership structure: empirical study from Jordan'. International Journal of Corporate Governance, 10(3-4), pp. 209-247.

Almasarwah, A. K., Omoush, A. M., and Alsharari, N. (2018). 'IFRS compliance and stock prices influence: evidence from Jordanian banks'. Banks \& bank systems, 13(3), pp. 24-35.

Wardhani, R., and Anggraenni, M. D. (2017). 'The effect of leverage and IFRS convergence on earnings management through real activities manipulation in Asia'. AJBA, 10(1), pp. 87-125.

Armstrong, C. S., Barth, M. E., Jagolinzer, A. D., and Riedl, E. J. (2010). 'Market reaction to the adoption of IFRS in Europe'. The Accounting Review, 85(1), pp. 31-61.

Ballas, A. A., Skoutela, D., and Tzovas, C. A. (2010). 'The relevance of IFRS to an emerging market: Evidence from Greece'. Managerial Finance, 36(11), pp. 931-948.

Ball, R., Robin, A., and Wu, J. S. (2003). 'Incentives versus standards: properties of accounting income in four East Asian countries'. Journal of Accounting and Economics, 36(1-3), pp. 235-270.

Ball, R. (2006). 'International Financial Reporting Standards (IFRS): pros and cons for investors'. Accounting and Business Research, 36(1), pp. 5-27.

Barth, M. E., Landsman, W. R., and Lang, M. H. (2008). 'International accounting standards and accounting quality'. Journal of Accounting Research, 46(3), pp. 467-498.

Ben-Nasr, H., and Cosset, J. C. (2014). 'State ownership, political institutions, and stock price informativeness: Evidence from privatization'. Journal of Corporate Finance, 29, pp. 179-199.

Beuselinck, C., Joos, P., Khurana, I. K., and Van der Meulen, S. (2010). Mandatory IFRS reporting and stock price informativeness. Tilburg University.

Bhattacharya, N., Ecker, F., Olsson, P. M., and Schipper, K. (2012). 'Direct and mediated associations among earnings quality, information asymmetry, and the cost of equity'. The Accounting Review, 87(2), pp. 449-482.

Bissessur, S. and Hodgson, A. (2012). 'Stock market synchronicity-an alternative approach to assessing the information impact of Australian IFRS'. Accounting \& Finance, 52(1), pp. 187-212.

Brüggemann, U., Hitz, J. M., and Sellhorn, T. (2013). 'Intended and unintended consequences of mandatory IFRS adoption: A review of extant evidence and suggestions for future research'. European Accounting Review, 22(1), pp. 1-37.

Budrina, M. (2014). The Impact of IFRS Adoption on Accrual-Based Earnings Management: Evidence from Russia. University of OULU.

Burgstahler, D. C., Hail, L., and Leuz, C. (2006). 'The importance of reporting incentives: Earnings management in European private and public firms'. The Accounting Review, 81(5), pp. 983-1016.

Callao, S. and Jarne, J. I. (2010). 'Have IFRS affected earnings management in the European Union?'. Accounting in Europe, 7(2), pp. 159-189.

Chalaki, P., Didar, H., and Riahinezhad, M. (2012). 'Corporate governance attributes and financial reporting quality: Empirical evidence from Iran'. International Journal of Business and Social Science, 3(15), pp. 223-229.

Chen, S. S. and Huang, C. W. (2013). 'The Sarbanes-Oxley Act, earnings management, and post-buyback performance of openmarket repurchasing firms'. Journal of Financial and Quantitative Analysis, pp. 1847-1876.

Christensen, H. B., Lee, E., Walker, M., and Zeng, C. (2015). 'Incentives or standards: What determines accounting quality changes around IFRS adoption?'. European Accounting Review, 24(1), pp. 31-61.

Cohen, D. A., Dey, A., and Lys, T. Z. (2008). 'Real and accrual-based earnings management in the pre-and post-Sarbanes-Oxley periods'. The Accounting Review, 83(3), pp. 757-787.

Cohen, D. A. and Zarowin, P. (2010). 'Accrual-based and real earnings management activities around seasoned equity offerings'. Journal of Accounting and Economics, 50(1), pp. 2-19.

Daske, H., Hail, L., Leuz, C., and Verdi, R. (2008). 'Mandatory IFRS reporting around the world: Early evidence on the economic consequences'. Journal of Accounting Research, 46(5), pp. 1085-1142.

Daske, H., Hail, L., Leuz, C., and Verdi, R. (2013). 'Adopting a label: Heterogeneity in the economic consequences around IAS/IFRS adoptions'. Journal of Accounting Research, 51(3), pp. 495-547.

Devalle, A., Onali, E., and Magarini, R. (2010). 'Assessing the value relevance of accounting data after the introduction of IFRS in Europe'. Journal of International Financial Management \& Accounting, 21(2), pp. 85-119.

Doukakis, L. C. (2010). 'The persistence of earnings and earnings components after the adoption of IFRS'. Managerial Finance, 36(11), pp. 969-980.

Doukakis, L. C. (2014). 'The effect of mandatory IFRS adoption on real and accrual-based earnings management activities'. Journal of Accounting and Public Policy, 33(6), pp. 551-572. 
DeFond, M. L., Hung, M., Li, S., and Li, Y. (2015). 'Does mandatory IFRS adoption affect crash risk?'. The Accounting Review, 90(1), pp. 265-299.

Dechow, P. M. and Dichev, I. D. (2002). 'The quality of accruals and earnings: The role of accrual estimation errors'. The Accounting Review, 77(s-1), pp. 35-59.

Dechow, P. M., Sloan, R. G., and Sweeney, A. P. (1995). 'Detecting earnings management'. Accounting Review, pp. $193-225$.

Dechow, P., Ge, W., and Schrand, C. (2010). 'Understanding earnings quality: A review of the proxies, their determinants and their consequences'. Journal of Accounting and Economics, 50(2-3), pp. 344-401.

Dichev, I. D., Graham, J. R., Harvey, C. R., and Rajgopal, S. (2013). 'Earnings quality: Evidence from the field'. Journal of Accounting and Economics, 56(2-3), pp. 1-33.

Ernst \& Young. (2006, 2006). IFRS: Observations on the implementation of IFRS. Ernst \& Young Publications. Retrieved from http://www2.eycom.ch/publications/items/ifrs/single/200609 observations on ifrs/200609 EY Observations on IFRS.pdf

Eng, L. L. and Mak, Y. T. (2003). 'Corporate governance and voluntary disclosure'. Journal of Accounting and Public Policy, 22(4), pp. 325-345.

Fernández, E., Iglesias-Antelo, S., López-López, V., Rodríguez-Rey, M., and Fernandez-Jardon, C. M. (2019). 'Firm and industry effects on small, medium-sized and large firms' performance'. BRQ Business Research Quarterly, 22(1), pp. 25-35.

Gillberto L. and Taboada, A. G. (2012). The impact of IFRS adoption on stock price informativeness. European Financial Management Association, 2012 Annual meeting, June 2012, Barcelona, Spain.

Graham, J. R., Harvey, C. R., and Rajgopal, S. (2005). 'The economic implications of corporate financial reporting'. Journal of Accounting and Economics, 40(1-3), pp. 3-73.

Gul, F. A., Srinidhi, B., and Ng, A. C. (2011). 'Does board gender diversity improve the informativeness of stock prices?'. Journal of Accounting and Economics, 51(3), pp. 314-338.

Horton, J., Serafeim, G., and Serafeim, I. (2013). 'Does mandatory IFRS adoption improve the information environment?'. Contemporary Accounting Research, 30(1), pp. 388-423.

Houqe, M. N., van Zijl, T., Dunstan, K., and Karim, A. W. (2012). 'The effect of IFRS adoption and investor protection on earnings quality around the world'. The International Journal of Accounting, 47(3), pp. 333-355.

Houqe, M. N., Easton, S., and van Zijl, T. (2014). 'Does mandatory IFRS adoption improve information quality in low investor protection countries?'. Journal of International Accounting, Auditing and Taxation, 23(2), pp. 87-97.

Hutton, A. P., Marcus, A. J., and Tehranian, H. (2009). 'Opaque financial reports, R2, and crash risk'. Journal of Financial Economics, 94(1), pp. 67-86.

Ibhagui, O. W. and Olokoyo, F. O. (2018). 'Leverage and firm performance: New evidence on the role of firm size'. The North American Journal of Economics and Finance, 45, pp. 57-82.

Ipino, E. and Parbonetti, A. (2017). 'Mandatory IFRS adoption: the trade-off between accrual-based and real earnings management'. Accounting and Business Research, 47(1), pp. 91-121.

Ismail, W. A. W., Kamarudin, K. A., Van Zijl, T., and Dunstan, K. (2013). 'Earnings quality and the adoption of IFRS-based accounting standards: Evidence from an emerging market'. Asian Review of Accounting, 21(1), pp. 53-73.

Jeanjean, T. and Stolowy, H. (2008). 'Do accounting standards matter? An exploratory analysis of earnings management before and after IFRS adoption'. Journal of Accounting and Public Policy, 27(6), pp.480-494.

Jones, J. (1991). 'Earnings management during import relief investigations'. Journal of Accounting Research, 29(2), pp. 193228.

Kalelkar, R. (2016). 'Audit committee diligence around initial audit engagement'. Advances in Accounting, 33(1), pp. 59-67.

Kim, J. B. and Shi, H. (2012). 'IFRS reporting, firm-specific information flows, and institutional environments: International evidence'. Review of Accounting Studies, 17(3), pp. 474-517.

Kim, J. B., Shi, H., and Zhou, J. (2014). 'International Financial Reporting Standards, institutional infrastructures, and implied cost of equity capital around the world'. Review of Quantitative Finance and Accounting, 42(3), pp. $469-507$.

Kothari, S. P., Leone, A. J., and Wasley, C. E. (2005). 'Performance matched discretionary accrual measures'. Journal of Accounting and Economics, 39(1), pp. 163-197.

Landsman, W. R., Maydew, E. L., and Thornock, J. R. (2012). 'The information content of annual earnings announcements and mandatory adoption of IFRS'. Journal of Accounting and Economics, 53(1-2), pp. 34-54.

Lee, H. A. (2019). 'The impact of IFRS adoption on management of bad debt expense and real operational activities: evidence from South Korea'. Asia-Pacific Journal of Accounting \& Economics, 26(4), pp. 434-456.

Lee, N. and Swenson, C. (2011). 'Earnings management through discretionary expenditures in the US, Canada, and Asia'. International Business Research, 4(2), p. 257.

Leuz, C. (2003). 'IAS versus U.S. GAAP: Information-asymmetry based evidence from German's new market'. Journal of Accounting Research, 41(3), pp. 445-72.

Lundholm, R. J. (1999). 'Reporting on the past: A new approach to improving accounting today'. Accounting Horizons, 13(4), pp. 315-322.

Lyimo, G. D. (2014). 'Assessing the measures of quality of earnings: Evidence from India'. European Journal of Accounting Auditing and Finance Research, 2(6), pp. 17-28.

Melumad, N.D. and Nissim, D. (2008), 'Line-item analysis of earnings quality'. Foundations and Trends in Accounting, 3(2-3), pp. 87-221. 
McInnis, J. and Collins, D. W. (2011). 'The effect of cash flow forecasts on accrual quality and benchmark beating'. Journal of Accounting and Economics, 51(3), pp. 219-239.

Mouselli, S., Jaafar, A., and Hussainey, K. (2012). 'Accruals quality vis-à-vis disclosure quality: Substitutes or complements?'. The British Accounting Review, 44(1), pp. 36-46.

Nera, M. M. and Murwaningsari, E. (2017). 'The effects of earnings quality, conservatism, and real earnings management on the company's performance and information asymmetry as a moderating variable'. International Journal of Economics and Financial Issues, 7(2), p. 309.

Oz, I. O. and Yelkenci, T. (2018). 'Examination of real and accrual earnings management: A cross-country analysis of legal origin under IFRS'. International Review of Financial Analysis, 58, p. 24-37.

Paananen, M. (2008). The IFRS adoption's effect on accounting quality in Sweden. Available at SSRN 1097659.

Paananen, M. and Lin, H. (2009). 'The Development of Accounting Quality of IAS and IFRS over Time: The Case of Germany'. Journal of International Accounting Research, 8(1), pp. 31-55.

Rajgopal, S. and Venkatachalam, M. (2011). 'Financial reporting quality and idiosyncratic return volatility'. Journal of Accounting and Economics, 51(1-2), pp. 1-20.

Rodriguez-Ariza, L., Martínez-Ferrero, J., and Bermejo-Sánchez, M. (2016). 'Consequences of earnings management for corporate reputation'. Accounting Research Journal.

Roychowdhury, S. (2006). 'Earnings management through real activities manipulation'. Journal of accounting and economics, 42(3), pp. 335-370.

Ruland, W., Shon, J., and Zhou, P. (2007). 'Effective controls for research in international accounting'. Journal of Accounting and Public Policy, 26(1), pp. 96-116.

Sellami, M. and Fakhfakh, H. (2013). 'Effect of the mandatory adoption of IFRS on real and accruals-based earnings management: Empirical evidence from France'. International Journal of Accounting and Economics Studies, 2(1), pp. 22-33.

Schipper, K. (2005). 'The introduction of International Accounting Standards in Europe: Implications for international convergence'. European Accounting Review, 14(1), pp. 101-126.

Srivastava, A. (2014). 'Why have measures of earnings quality changed over time?'. Journal of Accounting and Economics, 57(2-3), pp. 196-217.

Tsalavoutas, I., André, P., and Evans, L. (2012). 'The transition to IFRS and the value relevance of financial statements in Greece'. The British Accounting Review, 44(4), pp. 262-277.

Velury, U. and Jenkins, D. S. (2006). 'Institutional ownership and the quality of earnings'. Journal of Business Research, 59(9), pp. 1043-1051.

Wang, J. W. and Yu, W. W. (2015). 'The information content of stock prices, legal environments, and accounting standards: International evidence'. European Accounting Review, 24(3), pp. 471-493.

Watrin, C. and Ullmann, R. (2012). 'Improving earnings quality: The effect of reporting incentives and accounting standards'. Advances in Accounting, 28(1), pp. 179-188.

Yamani, A. and Almasarwah, A. (2019). 'Resistive factors of delaying IFRS adoption in Saudi Arabia listed firms'. Journal of Financial Reporting and Accounting, 17 (3), pp. 468-497

Zang, A. Y. (2012). 'Evidence on the trade-off between real activities manipulation and accrual-based earnings management'. The Accounting Review, 87(2), pp. 675-703.

(C) 2021 by the authors. Licensee ACRN Publishing, Austria, Editor in Chief Prof. Dr. Othmar M. Lehner. This article is an open access article distributed under the terms and conditions of the Creative Commons Attribution (CC BY SA) license

(https://creativecommons.org/licenses/by-sa/4.0/) 